\title{
Classica Americana. An Addendum to the Censuses of Pre-1800 Latin Texts from British North America
}

\author{
STUART M. MCMANUS
}

This article updates the censuses of North American Neo-Latin prose and poetry undertaken by the late Leo M. Kaiser, to which it adds over one hundred and fifty items, preserved largely in manuscript collections in New England. The genres run the gamut of early modern Latin, from academic oratory to occasional verse, while the addendum also includes works by a number of notable figures in early American history, including Increase Mather (1639-1723), James Logan (1674-1751), William Shirley (1694-1771), John Witherspoon (1722-1794), John Phillips (1770-1823) and Aaron Burr Sr. (1716-1757). The census is prefaced by an introduction that places the works in their broader intellectual context and briefly discusses the life and learning of British America's last humanist in the Renaissance mold, Ezra Stiles (1727-1795), whose Latinity makes up a significant proportion of the addendum. ${ }^{*}$

While in many ways less vibrant than its Novohispanic and Peruvian cousins to the south, the classicizing culture of the Thirteen Colonies and the antebellum United States continues to attract a steady stream of scholars intent on understanding its formative role in shaping the politics, education and art of early America. ${ }^{1}$ Nonetheless, partly because intellectual history has fallen from favor among early Americanists and partly because North American classicists, for the most part, are not yet willing to take ownership of such topics, there remains much to do. ${ }^{2}$ This is perhaps most obviously the case as regards the

\footnotetext{
* In addition to the archivists and librarians of the various collections that I visited in the course of compiling this addendum, I would also like to thank the following individuals for their help and encouragement: David Armitage, Ann Blair, Anthony Grafton, James Hankins, Thomas Keeline and Peter Mack. I am also grateful to the editors and anonymous reviewers of Humanistica Lovaniensia for their careful attention to my article at every stage of its production. All Latin spelling and capitalization have been classicized, and all punctuation has been modernized for ease of reading.

${ }^{1}$ On New Spain and Peru, and in particular on its Neo-Latin, see I. Osorio Romero, "Jano o la literatura neolatina de México (visión retrospectiva)", Humanistica Lovaniensia 30 (1981), 124-155; and Á. Helmer, El latín en el Perú colonial. Diglosia e historia de una lengua viva (Lima, 2013).

${ }^{2}$ The most notable studies of the Classical Tradition in British North America include M. Reinhold, Classica Americana. The Greek and Roman Heritage in the United States
} 
reading and writing of actual Latin texts, a topic that remains to a large extent unexplored.

This lack of attention to early American Latinity is unfortunate given the ubiquity of the ancient language in all domains of elite culture during this formative period of United States history. As is well known, Latin was the gymnasium in which all elite men (and some women) were trained, be it in the grammar school, the college or, as in the case of less well-heeled autodidacts like the polymath Benjamin Franklin, at home. Until around 1700, we must also remember, college students were expected to speak only Latin among themselves, and to be able to compose verse in the language. All this took place within an intellectual context in which to be illiterate in Latin was to be unable to access the best sources of knowledge in all fields, as the catalogues of colonial personal and college libraries make clear. This was the case for most disciplines until around 1750 and continued in highly specialist fields, like the natural sciences, medicine, law and classical studies for much longer than that. To lack Latin was also to be excluded from reading a huge body of influential literature in prose and verse, and to remain silent when in the company of learned men who did not share your vernacular, a common problem in the Americas where Englishmen mixed with Germans, Frenchmen, Scandanavians and other settlers. ${ }^{3}$

As in the rest of the Republic of Letters, the use of Latin in North America can be divided broadly into three periods: the humanist, the post-humanist and the neo-classical. The first, as Anthony Grafton has magisterially shown, lasted until the early decades of the eighteenth century, and saw Latin cultivated as a widespread language of communication, scholarship and serious composition by leading intellectual and literary figures. ${ }^{4}$ This was followed by a second phase, which covered the middle decades of the century, which saw considerable continuity in

(Detroit, MI, 1984); C.J. Richard, The Founders and the Classics. Greece, Rome, and the American Englightenment (Cambridge, MA, 1994); id., The Golden Age of the Classics in America. Greece, Rome, and the Antebellum United States (Cambridge, MA, 2009); C. Winterer, The Culture of Classicism. Ancient Greece and Rome in American Intellectual Life, 1780-1910 (Baltimore, MD, 2002).

${ }^{3}$ The conclusions of Françoise Waquet apply equally to early America: Latin, Or, The Empire of the Sign. From the Sixteenth to the Twentieth Century (London, 2001). The finest personal library in British North America was undoubtedly that of James Logan: E. Wolf II, The Library of James Logan of Philadelphia, 1674-1751 (Philadelphia, PA, 1974).

${ }^{4}$ A. Grafton, "The Republic of Letters in the American Colonies. Francis Daniel Pastorius Makes a Notebook", American Historical Review 117 (2012), 1-39. 
late Renaissance educational methods even as the Latinate humanist culture of the late Renaissance that it supported disappeared over the historical horizon. ${ }^{5}$ The third period, which crystalized in the second half of the eighteenth century, saw considerable continuity in the study of Latin per se, although now from new vernacular textbooks, using new Enlightenment methods and largely for the purpose of accessing classical texts, rather than as a language of regular communication and serious composition, albeit that such things continued in selected parts of Europe. 6

It was the classicist Leo M. Kaiser $(\uparrow 2001)$, who laid the foundations for the systematic study of North American Latinity. ${ }^{7}$ He produced scholarly editions of numerous texts in both prose and verse, placing them within their educational and political contexts. ${ }^{8}$ He also completed two largescale censuses of the Latin texts composed in the region before 1800 , one for prose and another for verse. ${ }^{9}$ Since his death there has been a steady trickle of new scholarship. ${ }^{10}$ However, there is nothing that can compare to Kaiser's heroic and longstanding efforts. This is particularly unfortunate in the case of his bibliographical work, a domain where today one might expect to make considerable advances thanks to improved cataloguing and the increasing availability of these catalogues online in a searchable form. In this vein, this article presents

\footnotetext{
${ }^{5}$ On post-humanism and this periodization in general, see S.M. McManus, The Global Lettered City. Humanism and Empire in Colonial Latin America and the Early Modern World (unpublished doctoral thesis, Harvard University, 2016).

${ }^{6}$ This neo-classical period is roughly equivalent to Reinhold's "Silver Age," although I date its beginnings somewhat earlier: Reinhold 1984 (as in n. 2), 194.

7 "Leo M. Kaiser Sr.", Chicago Tribune (21 February 2001).

${ }^{8}$ L.M. Kaiser, Early American Latin Verse, 1625-1825 (Chicago, IL, 1984); id., "In Pursuit of Eloquence. Three Latin Oratorical Efforts of John Leverett", Harvard Library Bulletin 26 (1978), 388-400

9 L.M. Kaiser, "Contributions to a Census of American Latin Prose, 1634-1800", Humanistica Lovaniensia 31 (1982), 164-189; id., "A Census of American Latin Verse, 1625-1825", Proceedings of the American Antiquarian Society 91.2 (1982), 197-299.

${ }^{10}$ E.g. A. Blair, "Neo-Latin in North America", in P. Ford, J. Bloemendal, C. Fantazzi (ed.), Brill's Encyclopedia of the Neo-Latin World (Leiden, 2014), 833-848; T. Keeline, S.M. McManus, "Benjamin Larnell, the Last Latin Poet at Harvard Indian College", Harvard Studies in Classical Philology 108 (2015), 621-642. There have also recently been several senior theses on North American Neo-Latin, which bespeak the ongoing appeal of the topic at the undergraduate level, in the Ivy League at least, e.g. T.R. Delwiche, In silvis Academia surgit. Latin Learning in 17th Century New England (unpublished senior thesis, Harvard University, 2018); C. Glandorf, The Mis-Education of Benjamin Larnell. The Story of the Last Indian Student at Colonial Harvard (unpublished senior thesis, Yale University, 2009).
} 
an addendum to Kaiser's two censuses of North American Latin in order that historians and literary scholars may better orientate themselves in this field.

This addendum was compiled almost by accident while the present author was conducting background research for a study of the classical rhetorical tradition and humanist political thought in the early modern world. The present author began his search for evidence of rhetorical education and classicizing public speaking in Latin with Kaiser's census of Neo-Latin prose, before systematically examining recent published scholarship on the topic and beginning his archival search in the leading university and regional archives in New England. As Latin texts in these collections were frequently catalogued incompletely or incorrectly (for example, oratio being misread as "oratorio", etc.), it soon became clear that the only way to identify examples of Latin oratory and declamation (that is to say practice orations delivered as part of the requirements of the colonial colleges) was to ask to see any and all the collection's material in Latin. ${ }^{11}$ At this point, it became clear that Kaiser's censuses, while exemplary for their time, were incomplete. The present author therefore began to keep an informal tally of Latin works written before 1800 , excluding commonplace books and student notes. Consequently, the reader must understand that this addendum cannot be read independently of Kaiser's earlier censuses, and that it does not pretend to complete the task that Kaiser began. Rather, it is hoped that this unintentional byproduct of another scholarly project will go some way to advancing the fields of Neo-Latin and classical reception studies in the United States. It also bears underlining that the author chose to mine only collections that were known to hold documents relating to notable educational and religious institutions, for example Harvard, Yale and the Moravian Church. The list therefore cannot be considered representative in any meaningful sense of the word, and certainly not if read by itself.

Of the Latin texts included in this addendum, the vast majority are works of prose and are preserved exclusively in manuscript. Of the genres represented, unsurprisingly given the original aim of the search, academic oratory forms the largest part followed by college declamations. Epistolography (both communicative and propaedeutic),

${ }^{11}$ On declamation at early Harvard, see P.G. Perrin, The Teaching of Rhetoric in the American Colleges Before 1750 (unpublished doctoral thesis, The University of Chicago, 1936), 136-141. 
occasional verse, the epitaph, the dedication and the thesis (that is to say the text of a public examination) are also well-represented. All these genres were already represented in large numbers in Kaiser's earlier censuses. Yet, what emerges most clearly from the addendum is that Latinity was not, as one might have thought from reading earlier scholarship, the sole domain of early America's Anglophone settlers. Indeed, Kaiser was largely unaware of the Latin of Pennsylvania's Dutch, German and Danish settlers. For instance, the Danish Moravian, Christian Wedsted (1720-1757), was a versatile Latin poet, whose verses range from an epyllion on his transatlantic voyage to celebrations of the birthdays of friends and neighbors. Perhaps the most important example of Moravian Latinity, however, is the Latin oration delivered in 1742 in Philadelphia by the founder of the revived Moravian Church, Nicholaus Ludwig, Count of Zinzendorf and Pottendorf (1700-1760), in which he publicly renounced his titles of nobility in the hope of gaining favor with the colony's less blue-blooded inhabitants. This meandering and fiendishly erudite speech represents simultaneously the height and nadir of North American late humanism, and caused a contemporary to remark: "thus ended all this parade to the no small astonishment of the company who generally concluded him cracked [...]. In short he appears a mere knight errant in religion, scarce less than Don Quixote was in chivalry. I am truly sorry for that very honest, but poor wavering man."12 Finally, Kaiser was also unaware of the Latinity of the British Caribbean, which is represented by the verses of Francis Williams (1702-1770).

Epistolography is also somewhat better represented in the addendum than in Kaiser's studies. For instance, we have a fascinating series of Latin letters to and from one of the first governors of Connecticut, John Winthrop, Jr. (1606-1676), as well as the letters of William Penn's secretary (and a notable scholar in his own right), James Logan (16741751). The variety of topics and addressees in these letters underline the importance of Latin as a language of communication in the Republic of Letters. This was especially the case when the letter had to cross national or confessional lines. When a Protestant minister wrote to a

12 Philadelphia, PA, Historical Society of Pennsylvania, James Logan Papers, 16701749, Collection 2011, Letter Book B, f. 28r-29r, at f. 28v. On the oration and its circumstances, see T. Keeline, S.M. McManus, "Aenigma Omnibus. The Transatlantic Late Humanism of Zinzendorf and the Early Moravians", forthcoming in Journal of the Warburg and Courtauld Institutes (2019). 
(usually French) Jesuit missionary, their only shared language was Latin, French seemingly not having gained the ascendency in the colonies until the mid-eighteenth century. To this varied corpus of letters can be added a number of bilingual English-Latin diaries, which constantly codeswitch depending on the topic and the shifting inclinations of the author. Of the diaries, probably the most unusual and interesting is the diary of Joseph "Handkerchief" Moody (1700-1753), the enigmatic pastor of York, Maine, who preached with his face partitially covered by a handkerchief and wrote his diary in a Latin cipher. Finally, the reader should note that among the authors listed are to be found some of the leading figures in early American history, including the Scottish-born signatory to the Declaration of Independence, John Witherspoon (1722-1794), the well-known commentator on the Salem Witch Trials, Increase Mather (1639-1723), the longstanding governor of Massachusetts, William Shirley (1694-1771), the first Mayor of Boston, John Phillips (17701823), and Aaron Burr Sr. (1716-1757), the father of the third Vice President of the United States and noted dueller, Aaron Burr, Jr. (17561836), among many other figures, who while not household names like Mather or Burr, are well-known to specialists.

This said, perhaps the Latinist to emerge most clearly from the addendum, and whom Kaiser mentioned only in passing, is the Connecticutborn Ezra Stiles (1727-1795). Stiles is a fascinating figure. He was a true Renaissance man, who during his long life cultivated Latin eloquence as well as devoting his considerable energy to mastering Hebrew, electricity and magnetism, historical demographics and land surveying. He was, in other words, a polymath in the mode of Benjamin Franklin, but with a more conventional academic background and a far deeper investment in the vanishing world of late humanism with its close connection to Renaissance scholarly practices and its emphasis on Latin as the primary language of scholarlship and communication among the learned. ${ }^{13}$ Indeed, as well as playing a leading role in the foundation of Brown University and educating several generations of New England worthies as tutor and later President of Yale, he is also notable for delivering what must number among the finest examples of North American Latin oratory: the funeral oration for the Governor of Connecticut, Jonathan Law (1674-1750); and an epideictic oration in

\footnotetext{
${ }^{13}$ On late humanism, see A. Grafton, "The World of the Polyhistors. Humanism and Encyclopedism", Central European History 18 (1985), 31-47.
} 
praise of Benjamin Franklin delivered when the newly famous author of Experiments and Observations on Electricity (1751) came to Yale to receive his honorary degree in July of $1753 .{ }^{14}$ As the last North American humanist in the late-Renaissance mold whose Latinity and engagement with the Classical Tradition have been almost entirely overlooked, it is therefore perhaps useful to conclude with some remarks about Stiles and his scholarly world in order to put some meat on the bare bones of this list of Latin texts.

\section{Ezra Stiles: America's Forgotten Latinist}

Ezra Stiles came from a family of noted scholars and Latin orators. His father, Isaac Stiles, had been educated at Yale (where he had delivered a Latin oration in 1722) before going onto a career as a teacher and a minister, and it was natural that Ezra should follow in his father's footsteps. ${ }^{15}$ The curriculum at Yale when Stiles attended in the 1740s, it is important to note, was, from our perspective, Janus-faced, as was typical of this post-humanist period in the history of the Classical Tradition. New, predominantly vernacular texts had for some time been pushing out older Latin handbooks in philosophy, history and natural science. ${ }^{16}$ However, the teaching of Latin grammar, rhetoric and declamation remained almost unaltered from the rhythms of the seventeenthcentury schoolrooms and colleges on both sides of the Atlantic. ${ }^{17}$ Indeed, there was no reason to change it. No grand theories had come to displace the late-humanist rhetorical curriculum, while it appears there was still the sense that Latin eloquence was the archetypal, if not the most commonly used, form of expression. Like generations of New Englan-

${ }^{14}$ L.W. Labree et al. (ed.), The Papers of Benjamin Franklin, vol. 3 (New Haven, CT, 1961), 109. Among American-born Latinists, he is perhaps second only to Urian Oakes (1631-1681): L.M. Kaiser, "The Unpublished Oratio Secunda of Urian Oakes, Harvard, 1675", Humanistica Lovaniensia 21 (1972), 387-412.

15 Isaac Stiles' oration is preserved in New Haven, CT, Beinecke Rare Book and Manuscript Library, Yale University, Ezra Stiles Papers, MP 17. On Stiles' father, see E.S. Morgan, The Gentle Puritan. A Life of Ezra Stiles, 1727-1795 (New Haven, CT, 1962), 1-3.

16 Ibid., $42-57$.

17 The best introduction to early modern British university education is: T.H. Aston (ed.), The History of the University of Oxford, vol. 4-5 (Oxford, 1986-1997). On academic oratory in particular, see K.L. Haugen, "Imagined Universities. Public Insult and the Terrae Filius in Early Modern Oxford", History of Universities 16 (2001), 1-31. For the case of John Milton, see J.K. Hale (ed.), Latin Writings: A Selection (Assen, 1998), 3-16. 
ders before him, Stiles studied Thomas Farnaby's Index rhetoricus (London, 1625) and declaimed in the learned languages on maxims taken from classical poetry, just as grammar school boys had done in Shakespeare's England. ${ }^{18}$ However, unlike many of his fellow students in this post-humanist period, who seem to have been content with a largely passive knowledge of Latin, Stiles seems to have had a particular affinity for Latin eloquence in general, and the Renaissance tradition of Latin public speaking in particular. This may have been due to the influence of his father. Whatever his motivation, Stiles Jr. took his training as a Latin orator in the humanist mold as seriously as all his other studies, even going as far as to prepare his declamations, which students were required to deliver one Friday per term, several months in advance, as is clear from the surviving manuscript evidence. ${ }^{19}$ Perhaps for this reason, Stiles' declamations stand out from those of his peers at both Yale and Harvard.

As a result of his skill in Latin public speaking in an age when few were cultivating it with the same vim and vigor as even the generation before, Stiles was continually called upon to deliver Latin orations as both an undergraduate and then later as tutor, a post he held between 1749 and 1755 . Reading these, it becomes clear that in contrast to many students and scholars who delivered academic orations in Latin in the mid-eighteenth century with little sense that they were continuing a tradition that was tied not only to ancient Rome but also Renaissance Europe, Stiles consciously saw himself following in the footsteps of his humanist forebears. For example, in his funeral oration for the philosopher and benefactor of Yale, George Berkeley (1685-1753), Stiles overtly compared his own act of commemoration to the funeral oration for Pope Pius V by the sixteenth century's foremost Ciceronian orator, Marc-Antoine Muret (1526-1585), as well as to a funeral oration for the church historian Caesare Baronio (1538-1607) delivered by Michele Angelo Buccio in Rome in 1607. In the funeral oration for Berkeley, he

${ }^{18}$ T.W. Baldwin, William Shakespere's Small Latine and Lesse Greeke, vol. 2 (Urbana, IL, 1944), 355-379.

${ }^{19}$ According to the 1745 Yale College Laws, F.B. Dexter, Biographical Sketches of the Graduates of Yale College with Annals of the College History, vol. 2 (New York, NY, 1896), 2-18, at 5: "On Friday each undergraduate in his order about six at a time shall declaim in the hall in Latin, Greek, or Hebrew and in no other language without special leave from the President; and shall deliver up his declamation to his tutor, fairly written and subscribed." 
also referred explicitly to recent examples of Latin oratory from Britain, including Dr. William King's controversial pro-Jacobite oration delivered for the opening of the Radcliffe Camera at Oxford in 1749, and a funeral oration for Frederick, Prince of Wales, delivered at Cambridge in $1751 .{ }^{20}$ Rather than an oddity of New England college life, or a fossil of an earlier age, or even a Neo-Roman implant, Stiles saw his oration as part of a coherent tradition stretching back to Renaissance Italy and from there to antiquity itself.

It was also during Stiles' time as tutor that Jonathan Law (16741750), the longstanding Governor of Connecticut, died, and the young humanist was called upon to deliver a Latin funeral oration, the last for a colonial governor. Given the importance of the occasion, great attention had to be paid to its composition and delivery. That the audience was expected to understand the oration is clear from the fact that Stiles gave a separate English language address to the Governor's widow, who, as a woman, was assumed not to understand the learned language. ${ }^{21}$ Since Law's governorship had been somewhat divisive, Stiles had to exercise a certain amount of tact, for we know that even as late as 1750 Latin orations could still spark controversy. Indeed, Stiles did not want to cause a scandal after the fashion of the aforementioned Dr. William King, the last humanist in the circle of Jonathan Swift and Alexander Pope, who gained notoriety when in 1749 he openly called for the return of the House of Stuart in a phrase that would become a popular Jacobite motto, "may that great guiding spirit of Britain return" (redeat ille magnus genius Britanniae), which caused him (in his own words) to be "attacked by all orders and professions, by all sects and religions and those of no religion, by giants and knights, squires and dwarfs, women and children." 22

${ }^{20}$ New Haven, CT, Beinecke Rare Book and Manuscript Library, Yale University, Ezra Stiles Papers, MP 143. Stiles mentioned the opening of the Radcliffe Camera ibid., MP 135, 10.

${ }^{21}$ Ezra Stiles, Oratio funebris pro exequiis celebrandis viri perillustris Jonathan Law (New London, CT, 1751), 13-15. The English version for Mrs Law is to be found in New Haven, CT, Beinecke Rare Book and Manuscript Library, Yale University, Ezra Stiles Papers, MP 105.

22 William King, Oratio in Theatro Sheldoniano habita idibus Aprilibus, MDCCXLIX. Die dedicationis Bibliothecae Radclivianae (London, 1750), 29-32. On the oration, see D. Greenwood, William King. Tory and Jacobite (Oxford, 1969), 193-233. For an account by King of the reception of his oration, see Cambridge, MA, Houghton Library, ms. Eng. 218.2, Boyle Family Papers, II, 30-33. Scholars of British Neo-Latin may be interested to learn that the Boyle Family Papers in the Houghton Library contain a number of unedited 
Finding the right turn of phrase was, of course, easier said than done given some of Law's more controversial policies, as the numerous surviving manuscript drafts composed from late-November 1750 onwards make clear. In the first draft, Stiles sailed too close to the wind by praising Law's stern reaction against the "Great Awakening", an evangelical movement in the 1730s and 1740s that had divided college and colony between the revivalist "new lights" and more conservative "old lights". ${ }^{23}$ Probably fearful that the "new light" members of the audience would react badly to this, Stiles decided to rewrite his earlier draft, removing any mention of the governor's opposition to religious renewal, and replacing it with an oblique reference to his steadfastness in the face of fickle public opinion and his constant attention to public affairs. ${ }^{24}$

The use of Latin and his reading of earlier humanist funeral orations, it should be noted, also fundamentally shaped the ideas and frame of reference of Stiles' Latin eulogy. As a textbook piece of lateRenaissance panegyric, both the drafts and the printed version exhibit the neo-Renaissance ideology of "virtue politics" and so couche Connecticut's political system in decidedly Neo-Roman terms. For instance, Stiles speaks of the colony's "leading men" (optimates) and "senators" (senatores) who are charged with preserving the state (salus reipublicae). ${ }^{25}$ Yet, no matter well-instituted the laws may be, they were not sufficient for a flourishing state. Good governance, Stiles argued, was a product of the personal virtue of leaders, who always had to keep before their eyes the immediate needs and temperament of the

late-humanist works by Dr. King and his contemporaries, including this unpublished poem in praise of the orator. Cambridge, MA, Houghton Library, ms. Eng. 218.2, Boyle Family Papers, III, 225: “Ad eruditissimum Gulielmum King authore I[oanne?] Merrick 1743:

Salve, o quem fandi seros comitatur ad annos copia et in patriam non temerata fides.

Quamquam atrae visu formae, quamquam horrida contra invidia atque auri stet malesuada fames,

pergis adhuc, iamque incepit circum irrita frontem ludere tempestas innocuusque furor.

Nil caeli metuunt rabiem quos iactat amicos Laelius et lauro cinxit Apollo sua."

${ }^{23}$ New Haven, CT, Beinecke Rare Book and Manuscript Library, Yale University, Ezra Stiles Papers, MP 100, 4. The religious struggles of the period in New Haven are outlined in S. Nissenbaum, The Great Awakening at Yale (Belmont, CA, 1972).

${ }^{24}$ Stiles 1751 (as in n. 21), 6.

25 J. Hankins, "Machiavelli, Civic Humanism, and the Humanist Politics of Virtue", Italian Culture 32 (2014), 98-109. 
governed in keeping with Cicero's famous maxim: "The wellbeing of the people should be the supreme law" (salus populi suprema lex esto). ${ }^{26}$ In this regard, the deceased governor had excelled all others. He had possessed the humility to consult with others on important matters, the resolve to stand against the will of the mob and the foresight to be a patron of learning and industry, including the first silk farm in Connecticut! In this way, Law served as an example of virtue and wisdom for imitation by those he has left behind:

Nor, dear listeners, should we think him wholly taken from us, nor totally lost, while his illustrious example assuredly speaks to us from the grave, and exhorts and urges us to seek the praiseworthy arts and virtues of every sort. ${ }^{27}$

Stiles' funeral oration for Law thus served a fundamentally parenetic function to spur listeners to follow in the governor's footsteps. It is clear then that Stiles saw no fundamental contradiction in delivering a Renaissance-style humanist funeral oration on the cusp of the French and Indian War.

As the world changed around him, Stiles continued to use Latin on important ceremonial occasions, such as commencement and the awarding of honorary degrees, and even expanded the number of occasions for Latin oratory at his provincial alma mater. ${ }^{28}$ At the same time, he also used Latin for more run-of-the-mill purposes. For instance, when he received gifts from students (a new waistcoat one year, a watch another), he wrote them short letters of thanks in Latin. ${ }^{29}$ With few opportunities for advancement at Yale and the pittance he received for serving as tutor not being sufficient to support a family, he was, however, soon forced to leave New Haven, and to seek employment in Newport, Rhode Island, eventually becoming minister of the Second Congregational Church. There he stayed for some twenty years, during which time he played an important role in the foundation and

${ }^{26}$ Stiles 1751 (as in n. 21), 5-6. Cf. Cic. Leg. 3.3.8.

${ }^{27}$ Stiles 1751 (as in n. 21), 11: "Neque hunc nobis, auditores, penitus ereptum, nec prorsus amissum existimemus, dum exemplar eius perillustre vel e tumulo eloquitur, et nos ad laudatarum artium et virtutum omnigenarum prosecutionem adhortatur et urget."

${ }^{28}$ Stiles introduced additional Latin speeches for when seniors who had passed the final exams were brought before the President: B.M. Kelley, Yale. A History (New Haven, CT, 1974), 104.

${ }^{29}$ E.g. New Haven, CT, Beinecke Rare Book and Manuscript Library, Yale University, Ezra Stiles Papers, MP 77, 9, 15. 
flourishing of a number of institutions connected in different ways to Latin learning, including Brown University and the Redwood Library and Athenaeum. He also famously struck up a friendship with the iterinent Rabbi, Raphael Hayyim Isaac Carregal (1733-1777) during the latter's short sojourn in Rhode Island. ${ }^{30}$

Elected President of Yale in 1778, he returned to the rostrum, delivering Latin orations throughout the 1780s and 1790s. As President, he also sought singlehandedly to revive the study of Hebrew, initially making it a compulsory subject, and leading by example by delivering orations in Hebrew [PLATE 1]. This was tremendously unpopular with the students, but a few did follow in his footsteps delivering Hebrew commencement orations. ${ }^{31}$ There was less resistance to his use of Latin. However, by this point the Renaissance world of the humanists had disappeared from view. Classicism was still king for both men and women in the new republic. ${ }^{32}$ However, the active use of Latin was a niche interest, kept alive by a few physicians and academics, and the last humanist in the Renaissance mold, the venerable Ezra Stiles.

Although he trained many students, Stiles was to be the last of his kind. This is perhaps best exemplified by the interests and capacities of one of of Stiles' notable students, St. John Honeywood (1763-1798), who studied under Stiles at Yale in the 1780s. Although better known today for his artistic skill and his poetry on George Washington, Honeywood was also a talented schoolboy Latinist, who was chosen to deliver the Latin valedictory oration at Yale's 1782 commencement. To commemorate the event, Honeywood presented Stiles with a fine manuscript copy, which included a beautiful prefatory image of a Muse offering Honeywood a copy of the oration outside the College, as well as a miniature profile of Stiles [PLATE 2]. In the illustration, the figure giving Stiles the oration is an unidentificable Muse, and there is no sense that Latin oratory has any connection to politics or diplomacy, or is a training ground for other sorts of eloquence as it had been in the

${ }^{30}$ Morgan 1962 (as in n. 15), 143-144.

31 New Haven, CT, Beinecke Rare Book and Manuscript Library, Yale University, Ezra Stiles Papers, MP 802. On Stiles Hebrew scholarship, see A. Chiel, "Ezra Stiles. The Education of a 'Hebrician'”, American Jewish Historical Quarterly 60.3 (1971), 230-233; S. Goldman, God's Sacred Tongue. Hebrew and the American Imagination (Chapel Hill, NC, 2004), 52-73.

${ }^{32}$ C. Winterer, The Mirror of Antiquity. American Women and the Classical Tradition, 1750-1900 (Ithaca, NY, 2007). 
age of Muret. Instead, as Honeywood's lyre suggests, Latin oratory was an ornamental and highly niche literary pursuit. It was no longer the archetypal eloquence or the tool of the scholar-statesman, as classical languages were now mere tools to access selected ancient texts, such as Cicero's orations or the New Testament, with the latter not incidentally appearing under the Muse's feet. Unlike Stiles, the young orator does not seem to have seen himself as part of any lineage beyond the previous student orators at Yale College who undertook his prestigious but somewhat odd ceremonial task, and, probably much to Stiles' chagrin, Honeywood did not even have the Latinity to recognize his slip of the pen in the motto below the image (rectius Yalensis). ${ }^{33}$ Stiles would die in 1795 and with him the humanist tradition in North America.

${ }^{33}$ New Haven, CT, Beinecke Rare Book and Manuscript Library, Yale University, Ezra Stiles Papers, MP 820; presentation copy in ibid., MP 821. His most famous poem is: St John Honeywood, A Poem, on Reading President Washington's Address, Declining a Re-Election to the Presidency (Albany, NY, 1796). 


\section{An Addendum to Kaiser's Censuses of North American Latin}

[1] 1639 - John Winthrop, Jr., Letter to Jacobus Golius (dated 20 November 1639)

Boston, MA, Massachusetts Historical Society, Winthrop Family Papers, ms. N-262, I, 129 (ms. not seen).

Printed in A.B. Forbes (ed.), Winthrop Papers, vol. 4 (Boston, MA, 1944), 155-156 (online: www.masshist.org/publications/winthrop).

Incipit: "Decimus iam annus est."

[2] 1645 - Charles D'Aulnay de Charnisay, Letter to John Winthrop, Jr. (dated 3 November 1645)

Boston, MA, Massachusetts Archives, II, 491, 491A, 491B (ms. not seen).

Printed in A.B. Forbes (ed.), Winthrop Papers, vol. 5 (Boston, MA, 1947), 48-49.

Incipit: "Tuum tuorumque confoederatorum."

[3] 1645 - John Winthrop, Jr., Diary

New Haven, CT, Beinecke Rare Book and Manuscript Library, Yale University, General Manuscripts Miscellany, Group 274, Folder 60 (ms. not seen).

Printed in A.B. Forbes (ed.), Winthrop Papers, vol. 5 (Boston, MA, 1947), 51-54.

Incipit: "Novembris 11 die Martis hora III iter incepimus."

[4] 1650 - John Winthrop, Jr., Letter to Paul Marquart Schlegel (dated 10 November 1650).

Ms. not seen. Printed in M. Freiberg (ed.), Winthrop Papers, vol. 6 (Boston, MA, 1992), 78-79.

Incipit: "Praeteriti sunt aliquot menses."

[5] 1650 - John Winthrop, Jr., Letter to Johannes Tanckmarus (dated 10 November 1650)

Ms. not seen. Printed in M. Freiberg (ed.), Winthrop Papers, vol. 6 (Boston, MA, 1992), 82.

Incipit: "Accepi tuas literas ante aliquot menses."

[6] ca. 1650 - Seaborn Cotton, Letter to John Cotton (s.d.)

Boston, MA, New England Historic Genealogical Society Library, ms. Cb 1031, 87-88 (ms. not seen). 
Printed in S. Bush, Jr. (ed.), The Correspondence of John Cotton (Chapel Hill, NC, 2001), 474-475.

Incipit: "Cum ab ingratitudine non secus."

[7] ca. 1650 - Michael Wigglesworth, Fragments of Three Academic Orations Introducing Theses/Quaestiones

Cambridge, MA, Harvard University Archives, HUC 8650.394, 92-118 (paginated).

92-113 An Academic Oration on Human Anatomy.

Incipit: "Postquam angustissima magni mundi praeconia."

114-115 An Academic Oration on the Soul.

Incipit: "Vereor, auditores, ne grati."

117-118 A Fragment of an Academic Oration.

Incipit: "Memini comilitionum, erudita cohors."

[8] 1651 - Gabriel Druillettes, S.J., Letter to John Winthrop, Jr. (dated 1 January 1651)

Ms. not seen. Printed in Epistola reverendi patris Gabrielis Dreuillettes [sic], Societatis Iesu presbyteri, ad dominum illustrissimum, dominum Joannem Wintrop, scutarium (New York, 1864), 5-13; M. Freiberg (ed.), Winthrop Papers, vol. 6 (Boston, MA, 1992), 87-89.

Incipit: "Quoniam per altas iam hyemis nives."

[9] 1651 - John Winthrop, Jr., Letter to Paul Marquart Schlegel (dated 27 December 1651)

Ms. not seen. Printed in M. Freiberg (ed.), Winthrop Papers, vol. 6 (16501654) (Boston, MA, 1992), 154.

Incipit: "Post acceptas tuas literas."

[10] 1651 - John Winthrop, Jr., Letter to Johannes Tanckmarus (dated 27 December 1651)

Ms. not seen. Printed in M. Freiberg (ed.), Winthrop Papers, vol. 6 (Boston, MA, 1992), 156.

Incipit: "Aliquot menses post acceptas tuas literas."

[11] 1670-1671 - Samuel Phipps, Declamations in Latin and Greek from Harvard College

Boston, MA, Massachusetts Historical Society, ms. S-154.

2r-3r Declamation (dated 27 July 1670).

Incipit: "Nunc ex praeterito discas formam."

3r-4r Declamation.

Incipit: "Qualibus in rebus." 
4r-6r Declamation on Sponte tua contentus abi ne flebilis absit.

Incipit: "Fortuna $[\ldots]$ ingenua."

8v-10r Declamation on Mercurius semper vivat.

Incipit: "Suum nunc irridans."

12r-13r Declamation delivered before graduation in 1671 on Ast ego de visu cum laetus numen adoro.

Incipit: "Communi, viri apollinaris, humani generis natione."

13r-14v Declamation.

Incipit: "Hic variis et oblectis."

\section{[12] 1675 - Increase Mather, Catechismus logicus}

Worcester, MA, American Antiquarian Society, Manuscript Octavo Volumes, P (“Walter Price Notebook, 1692-1693”) (ms. not seen).

New Haven, CT, Beineke Library, General Manuscripts Miscellany, 142 ("Commonplace Book of John Clark") (ms. not seen).

Printed in 'Increase Mather's Catechismus Logicus (1675), Translated and Edited by Rick Kennedy and Thomas Knoles", Proceedings of the American Antiquarian Society 109 (1999), 183-223.

Incipit: "Quid est dialectica?"

\section{[13] 1678 - John Cotton, Fragment of a Letter to Increase Mather}

Boston, MA, Boston Public Library, ms. Am. 1502, vol. 2, no. 69.

Incipit: "Quem summo officio summaque observantia tibi antehac."

\section{[14] 1686 - Peter Daillé, Letter to Increase Mather}

Boston, MA, Boston Public Library, ms. Am. 1502, vol. 6, no. 20. Incipit: "Dominus Selyns in genere solummodo mihi retulit."

\section{[15] 1687 - Increase Mather, Draft of a Letter to Wolferdus}

Boston, MA, Boston Public Library, ms. Am. 1502, vol. 6, no. 53. Incipit: "Congratus tuus mihique amicissimus dominus Henricus Selijus."

[16] 1688 - Daniel Francis Pastorius, A Description of Pennsylvania Addressed to Georg Leonhard Modelius (dated 1 December 1688)

No surviving ms. Printed in Monatliche Unterredungen einiger guten Freunde (Leipzig, Gleditsch, April 1691), 281-288.

Incipit: "Restat brevem Pensylvaniae Chorographiam subnectere."

\section{[17] 1686-1690 - Joseph Belcher, Eleven Latin Declamations}

Cambridge, MA, Houghton Library, ms. Am. 1997, f. 18r-42r (online: www.hollis.harvard.edu).

Transcribed in Delwiche 2018 (as in n. 10). 
1) f. 18r-21r: Declamation on Quo semel est imbuta recens servabit odorem / testa diu [Hor. Ep. 1.2.69-70].

Incipit: "Quamvis in hoc dicendi genere, in tanta litteratorum praesentia, auditores candidissimi, non sum versatus."

2) f. 22r-26r: Declamation on Sed famam extendere factis / hoc virtutis opus [Verg. Aen. 10.468].

Incipit: "Cum singulis vestrum, auditores doctissimi, virtutis omnium praestantissimae amor."

3) f. 26r-29r: Declamation on Pudor iuveni dictus seni dedecus. Incipit: "Cum in hoc loco functurus officio, colluditores doctissimi."

4) f. 29r: Fragment of declamation on Scilicet est cupidus studiorum quisque suorum / tempus et asueta ponere in arte iuvat [Ov. Pont. 1.35-36].

Incipit: "Indubitatae veritatis axioma hoc est."

5) f. 30r-31r: Declamation on Scribimus indocti doctique poemata passim, / hic error tamen et levis haec insania quantas / virtutes habeat sic collige [Hor. Ep. 2.1.117]."

Incipit: "Ex omnibus fere nostris rebus ac studiis, doctissimi auditores."

6) f. 31v-33v: Declamation on Multum scire est vita iucundissima.

Incipit: "Aliquibus excellentia authoris citati."

7) f. 33v-35r: Declamation on Dicitur innocuas ut agat facundia causas / protegit haec sontes immeritosque premit [Ov. Trist. 2.273-274].

Incipit: "Cum saepenumero ex multis humanarum rerum casibus."

8) f. 35v-36v: Declamation on Magis consiliis quam armis bella geruntur, illa quidem faciunt iussa sed ista iubent.

Incipit: "Si quicquam, auditores doctissimi, ad magni, permagni commodi conservationem."

9) f. 36v-37v: Declamation on Addiscas veterum clarissima scripta virorum. Incipit: "Omnibus fere rebus mentis acie."

10) f. 38r-39r: Declamation on Vita rustica est vita pessima.

Incipit: "Si dicendi artificium et persuadendi studium."

11) f. 39r-40r: Declamation on Romani maximus autor Tullius eloquii.

Incipit: "Cogitanti mihi, auditores vere docti, annales veterum."

[18] 1694 - Johannes Kelpius, Diarium

Philadelphia, PA, Historical Society of Pennsylvania, ms. Am. 0880.

Printed in J.F. Sachse (ed.), The Diarium of Magister Johannes Kelpius (Lancaster, PA, 1917).

[19] 1702 - Anonymous, Epitaph of James Fitch, an Early Missionary in Connecticut

New Haven, CT, Beinecke Rare Book and Manuscript Library, Yale University, General Manuscript Miscellany, Group 2837, Folder 1. 
Incipit: "In hoc sepulchro depositae sunt reliquiae viri vere reverendi domini Jacobi Fitch.”

\section{[20] 1705 - William Hutchinson, Oratio salutatoria et valedictoria}

Boston, MA, Massachusetts Historical Society, ms. S-595.

Incipit: "Athenius [sic] cum cogeretur de gloria coram Philone disserere."

Incipit: "Tui enim excitamur virtute et doctrina, quam utramque ita coniungis."

\section{[21] 1710-1714 - Thomas Foxcroft, Latin Declamations}

Cambridge, MA, Harvard University Archives, HUM 68, Box 1, Folders 24 (online: www.hollis.harvard.edu).

Folder 2: Declamations on Age! Age! Tu reconciliati simus diabolumque exoculemus (paginated).

1-6 Incipit: "Scientia vel disciplina huius proverbi significans."

7-13 Incipit: "Maxime de vindicato malo."

Folder 3 (s.f.): Declamation in In laudem agriculturae vitaeque ruralis (dated 11 August 1711).

Incipit: "Virgilius inter poetas eminentissimus in dicendo."

Declamation on In laudem artis bellicae.

Incipit: "Nullius ingenii nec morum sane puer."

Declamation on Ut sit mens sana in corpore sano [Iuv. Sat. 10.356].

Incipit: "Qui ex hoc loco non verba faciunt."

Folder 4: Thesis Defended in Harvard College.

Incipit: "Divisio debet constare partibus paucissimis."

[22] ca. 1711 - Benjamin Larnell, Poetical Exercise in Hexameters on the Fable of the Fox and the Weasel

Boston, MA, Massachusetts Historical Society, ms. S-143.

Printed in T. Keeline and S.M. McManus, "Benjamin Larnell, the Last Latin Poet at Harvard Indian College", Harvard Studies in Classical Philology 108 (2015), 621-642.

Incipit: "Esurie longa tenuis vulpecula quondam."

[23] 1712 - Anonymous, A Pact Only to Speak Latin Among Themselves Signed by Junior and Senior Sophisters at Harvard College (dated 23 August 1712)

Cambridge, MA, Harvard University Archives, HUD 712.90 VT (online: www.hollis.harvard.edu).

Incipit: "Universis et singulis." 


\section{[24] 1714 - Thomas Foxcroft, Commencement Orations}

Cambridge, MA, Harvard University Archives, HUM 68 Box 1, Folder 8-9 (online: www.hollis.harvard.edu).

Folder 8: Oratio salutatoria apud Cantabrigienses habita in solennibus academiae gestis et fieriis. Ad nonas quintiles anno epochae Christianae 1714. Incipit: "Si quae, auditores, unius cuiusque ordinis admodum ornati." Folder 9: Oratio valedictoria in aula academiae Harvardinensis.

Incipit: "Auditores unius cuiusque ordinis admodum ornati, mos haudquaquam reprehendendus."

\section{[25] 1714 - Thomas Foxcroft, Theses Defended at Harvard College}

Cambridge, MA, Harvard University Archives, HUM 68 Box 1, Folder 4, s.f. (online: www.hollis.harvard.edu).

Thesis on Divisio debet constare partibus paucissimis.

Incipit: "Qui defendere iniquos."

Thesis on Demonstratio est syllogismus scientiam pariens.

Incipit: "Si ita tum demonstratio est."

Thesis on Forma dat esse rei.

Incipit: "Forma definitur esse id, quo semper quod aliud tale est."

Thesis on An syllogismo non debent esse plures termini, aut pauciores tribus.

Incipit: "Sunt tria themata simplicia."

Thesis on An motus fieri possit in instanti.

Incipit: "Cum duum sunt generum."

Thesis on An tria sint principia generationis corporis naturalis.

Incipit: "Vix de ulla re."

Thesis on Proprium non declarat quid res sit.

Incipit: "Proprium non declarat quaenam sit rei essentia."

Thesis on Simile non agit in simile.

Incipit: "Quae sunt similia qualitate, gradu et activitate."

Ibid., Folder 6: Thesis on Lux est corpus.

Incipit: "Veritatem huiusce propositionis."

Ibid., Folder 7: Thesis on Elementa in propriis suis locis gravitant et levitant. Incipit: "Quadrusolium [sic] Aristoteles elementorum numerum."

Ibid., Folder 10: Thesis on Non datur generatio spontanaea.

Incipit: "Non datur generatio spontanaea a pluribus physiologis illustribus pro certo."

\section{[26] 1715 - Benjamin Gibson, A Valedictory Poem for the Visit of the} Selectmen to Boston Latin School

Boston, MA, Massachusetts Historical Society, Miscellaneous Bound Manuscripts Collection, Filed at 27 August 1715.

Incipit: "Tu mihi praeceptor reverendeque docte supreme." 
[27] 1717 - Thomas Foxcroft, Oratio valedictoria in aula Academiae Harvardiensis habita

Cambridge, MA, Harvard University Archives, HUM 68, Box 1, Folder 9.

Incipit: "Auditores unius cuiusque admodum ornati."

[28] 1717 - Samuel Johnson, Valedictory Oration Delivered at Yale College

New York, NY, Columbia University Library, Samuel Johnson Papers 17101971, ms. 0679 (ms. not seen).

Printed in P.G. Perrin, "The Teaching of Rhetoric in American Colleges before 1750" (unpublished doctoral thesis, The University of Chicago, 1936), 203-211.

Incipit: "Ad haec rostra denuo assurgo."

[29] 1717 - Francis Daniel Pastorius, A Letter to Lloyd Zachary (dated 20 December 1717)

Philadelphia, PA, Historical Society of Pennsylvania, Francis Daniel Pastorius Papers, vol. 5 (Letter Book), 34.

Incipit: "Corditus, dilecte Loyde"

[30] 1717 - Francis Daniel Pastorius, Letter to Lloyd Zachary (dated 31 December 1717)

Philadelphia, PA, Historical Society of Pennsylvania, Francis Daniel Pastorius Papers, vol. 5 (Letter Book), 34-35.

Incipit: "Epistolium meum Laconicum responsionem."

[31] 1718 - John Eyre, Oratio salutatoria, habita in comitiis apud Cantabrigienses Harvardum, sexto Julii, 1718

Cambridge, MA, Harvard University Archives, HUC 6718.25.

Incipit: "Si quid est in me ingenii cultus aut litterarum."

\section{[32] 1718 - James Pierpoint, Oratio salutatoria}

New Haven, CT, Beinecke Rare Book and Manuscript Library, Yale University, Early Yale Documents, Box 2, Folder 99.

Incipit: "Proxime generosissimo, perillustres, ac eximio huius boni fontis maecenati."

[33] 1719 - Francis Daniel Pastorius, Letter to Lloyd Zachary (dated 19 December 1719)

Philadelphia, PA, Historical Society of Pennsylvania, Francis Daniel Pastorius Papers, vol. 5 (Letter Book), 108-110.

Incipit: "Amiklas silentium perdidit." 
[34] 1720 - Jonathan Edwards, Valedictory Oration at Yale College (dated September 1720)

New Haven, CT, Beinecke Rare Book and Manuscript Library, Yale University, General Manuscripts, 151, Jonathan Edwards Papers, Box 21, Folder 1264.

Incipit: "Quando meipsum locutum et locuturum, viri audientes amplissimi, in medio conventus."

\section{[35] 1720-1724}

\section{Joseph "Handkerchief” Moody, Diary}

Portland, ME, Maine Historical Sociey, ms. 1297 (ms. not seen).

Translated in P. McIntire, Handkerchief Moody, the Diary and the Man (Portland, ME, 1981).

\section{[36] 1721}

James Logan, Letter to Johann Albrecht Fabricius (dated 11 November 1721)

Philadelphia, PA, Historical Society of Pennsylvania, Logan Family Papers, vol. 6 (Letter Book III), 20-22.

Partly printed in E. Wolf II, The Library of James Logan of Philadelphia 1674-1751 (Philadelphia, PA, 1974), 401-402.

Incipit: "Dum undequaque a musarum alumnis."

[37] 1721 - Joseph Morgan, Letter to Cotton Mather on Arminianism (dated III Kalendis Septembris 1721)

Worcestor, MA, American Antiquarian Society, Curwen Family Papers, Box 2, Folder 1.

Incipit: "Maio praeterito epistulam manuscriptam incluso."

\section{[38] 1722 - Isaac Stiles, Oratio valedictoria}

New Haven, CT, Beinecke Rare Book and Manuscript Library, Yale University, Ezra Stiles Papers, MP 17.

Incipit: "Quoniam in usu viros inter omnes omnium civiles seculorum."

[39] 1725 - Benjamin Colman, Draft of Letter to Benjamin Avery (dated 8 June 1725)

Boston, MA, Massachusetts Historical Society, Benjamin Colman Papers, ms. N-1013, dated 1725, Box 1, Folder 12 (online: www.masshist.org).

Incipit: "Boniquitatem vestram bibliothecae collegii Harvardini."

[40] 1727 - James Logan, Letter to Johannes Fabricius about an Edition of Euclid (dated 29 December 1727)

No surviving ms. 
Hermann Samuel Reimarus, Commentarius de vita et scriptis Iohannis Alberti Fabricii (Hamburg, 1737), 291-295.

Incipit: "Euclidis editio est Henrici Stephani Avi."

[41] 1730 - James Logan, Letter to George Michael Weiss (dated 23 May 1730)

Philadelphia, PA, Historical Society of Pennsylvania, Logan Family Papers, vol. 6 (Letter Book III), 264

Incipit: "Cum nuper in aedibus meis de rebus tuis."

[42] 1733 - Chester Williams, Oratio ad examen, Julii 1733

New Haven, CT, Beinecke Rare Book and Manuscript Library, Yale University, Ezra Stiles Papers, MP 28.

Incipit: "Plus millies salvete, viri praeclarissimi."

\section{[43] 1734 - John Mascarene, Letter to his Father, Paul Mascarene}

Cambridge, MA, Houghton Library, ms. Am. 813, Item 16 (online: www.hollis.harvard.edu).

Incipit: "Accepi tuas literas, quas misisti ad me."

[44] 1734 - James Logan, Letter to Johann Albrecht Fabricius (dated Ides of December 1734)

Philadelphia, PA, Historical Society of Pennsylvania, James Logan Papers, 1670-1749, Collection 2011, Box 1, Folder 3.

Incipit: "Cum ante duodecim annos literas ad te darem."

[45] 1734 - Stephen Lauverjat, S.J., Letter to Joseph Seccombe (dated 13 April 1734)

Boston, MA, Massachusetts Historical Society, Benjamin Colman Papers, ms. N-1013, dated June-September 1734, Box 1, Folder 22 (online: www.masshist.org).

Incipit: "Quam huic adiungo epistolam, rogo te."

\section{[46] 1736 - Edward Winslow, Oratio valedictoria}

Cambridge, MA, Harvard University Archives, HUC 6736.94.

Incipit: "Quid restat, auditores celeberrimi, sole iam ad occasum properante."

[47] 1736 - James Logan, Letter to Richard Mead (dated IV Ides of July 1736)

Philadelphia, PA, Historical Society of Pennsylvania, James Logan Papers, 1670-1749, Collection 2011, Letter Book A, f. 6v-7r.

Incipit: "Quod ego homo a patria." 
[48] 1737 - James Logan, Letter to Richard Mead (dated 26 July 1737)

Philadelphia, PA, Historical Society of Pennsylvania, James Logan Papers, 1670-1749, Collection 2011, Box 1, Folder 3.

Incipit: "Cum amicus meus Petrus Collison."

[49] 1737 - James Logan, Letter to Richard Mead (dated 26 November 1737)

Philadelphia, PA, Historical Society of Pennsylvania, James Logan Papers, 1670-1749, Collection 2011, Letter Book A, f. 37v-38r.

Incipit: "Cum in hac lingua tibi scribere inceperim."

[50] 1738 - James Logan, Letter to Abraham Gronovius (dated X Kalendis Decembris)

Philadelphia, PA, Historical Society of Pennsylvania, James Logan Papers, 1670-1749, Collection 2011, Box 1, Folder 3.

Incipit: "Literas tuas Lugduni Batavorum."

[51] 1738 - James Logan, Letter to Linnaeus (dated 17 October 1738)

London, Royal Linnaean Society, ms. LS, IX, 442-443

(online: http://linnaeus.c18.net/Doc/index.php).

Philadelphia, PA, Historical Society of Pennsylvania, James Logan Papers, 1670-1749, Collection 2011, Box 1, Folder 3.

Incipit: "Literas tuas Amstaelodami."

[52] 1739 - John Mascarene, Declamation on famam extendere factis hoc virtutis opus [Verg. Aen. 10.468-469]

Cambridge, MA, Houghton Library, ms. Am. 813, Item 18 (online: www.hollis.harvard.edu).

Incipit: "Omnibus, quos studium gloriae acquirendae incendit."

[53] 1739 - S. Langdon, Verses in Hexameters Addressed to John Mascarene (dated April 1739)

Cambridge, MA, Houghton Library, ms. Am. 813, Item 23 (online: www.hollis.harvard.edu).

Incipit: "En tibi parve puer nunquam mea gratia cessat."

[54] 1739 - John Mascarene, Fragment of an Academic Oration

Cambridge, MA, Houghton Library, ms. Am. 813, Item 27 (online: www.hollis.harvard.edu).

Incipit: "Quamvis auctoritas huiusce senatus honorandae et venerandae." 
[55] 1739 - James Logan, Draft of De plantarum generatione

Philadelphia, PA, Historical Society of Pennsylvania, James Logan Papers, 1670-1749, Collection 2011, Box 2, Folder 121.

Incipit: "Cum de generatione tum stirpium."

\section{[56] 1739 - John Burt, Diary for 1739}

Worcester, MA, American Antiquarian Society, John Burt, Diaries for 1737 and 1739, vol. 2.

Incipit: "Ivi ad salutandum."

[57] 1740 - James Logan, Letter to Johannes Fabricius (dated Nonis Decembris 1735)

No surviving ms. Printed in Miscellaneae Observationes Criticae Novae 11.1 (1740), 91-113.

Incipit: "Literas tuas omnino iuncundissimas."

[58] 1740 - Thomas Prince, Jr., Oratio salutatoria et valedictoria

Boston, MA, Massachusetts Historical Society, ms. S-701.

1) f. 2r-5v: Prolusio oratoria in feria accademiae vernali, valedictoria oratio in aula academiae Harvardinae habita Martii 25, 1740.

Incipit: "Hodierna dies, spectatissima undiquaque corona."

2) f. 8r-11v: Oratio salutatoria Cantabrigiae in comitiis habita 27 Martii 1740. Incipit: "Luce quam alma, auditores spectatissimi, quam iucunda."

[59] ca. 1740 - [John Mascarene?], Letter of Congratulations to the New Governor of Massachusetts

Cambridge, MA, Houghton Library, ms. Am. 813, item 19 (online: www.hollis.harvard.edu).

Incipit: "Ornatissime et excellentissime vir, gratulationes tibi."

[60] 1741-1752 - Materials Relating to the Visit of the Governor of Massachusetts, William Shirley, to Harvard College

Cambridge, MA, Harvard University Archives, UAI 20.741, s.f.

William Shirley, Oration delivered at Harvard (two copies).

Incipit: "Praeses admodum colende, viri egregiae maiestatis."

Anonymous [Paul Mascarene?], Letter to William Shirley.

Incipit: "Gratulationes tibi, quem regia maiestas in suprema sede magistratus Masschutensis [sic] instituit."

Anonymous [Paul Mascarene?], Letter to Henry Flynt Concerning the Oration.

Incipit: "Orationem ad Harvardinos excellentissimi domini domini Sherli." 
[61] 1742 - Nicolaus Ludwig von Zinzendorf, Epistola ad bonos Pensilvaniae cives Christo non inimicos, ob conversationis difficultatem taliter qualiter Latino idiomate conscripta, et dexteritati cordati interpretis, duce providentia, pie concredita (Philadelphia, PA, 1742)

Incipit: "Homines qua tales."

[62] 1742 - Nicolaus Ludwig von Zinzendorf, Oratio (Philadelphia, PA, 1742)

A partial ms. version in Bethlehem, PA, Moravian Archives, PP Zdf. 39. Incipit: "Quae nobis hodie mane lucet."

[63] 1742 - Anonymous, Oratio valedictoria (dated 6 July 1742)

New Haven, CT, Yale University, Sterling Library, RU 140, Box 4, Folder 37. Incipit: "Inter coronam splendidissimam virorum celeberrimorum."

[64] 1742 - Orations Given at Meetings of the Harvard Latin Society

Cambridge, MA, Harvard University Archives, HUD 3511.5500, s.f. (online: www.hollis.harvard.edu).

Oration dated 14 April 1742 by Hitchcock Sr.

Incipit: "Quandoquidem, viri maximi honorandi, plerisque nostrum aliquod." Oration dated 21 April 1742 by Cotton Bourn.

Incipit: "Quanta voluptate, quanta delectatione, animique."

Oration dated 28 April 1742 by William Bourn (on Verecundia inutilis viro egenti).

Incipit: "Inter omnes aequisitiones humanas eruditio."

Oration dated 5 May 1742 by William Pyncheon.

Incipit: "Animo mecum ante perito meimetipsius, auditores candidissimi."

Oration dated 12 May 1742 by William Lawrence.

Incipit: "Ingrati vitium animi humano genere toto."

Oration dated 19 May 1742 by Hitchcock, Jr.

Incipit: "Socii, salvete, semper permultum honorandi."

Oration dated 17 June 1742 by Johnathon Mayhow.

Incipit: "Quandoquidem socii literati mihi."

[65] 1743-1746 - Ezra Stiles, Declamations Delivered at Yale College

New Haven, CT, Beinecke Rare Book and Manuscript Library, Yale University, Ezra Stiles Papers, MP 37 (paginated).

5-8 Declamation on Ferae instar annus currit.

Incipit: "Quandoquidem in usu inter iuvenes scholasticosve sedis huiusce."

9-10 Declamation on Ne sit securus qui non est tutus ab hoste.

Incipit: "Ineptissimus ad dicendum remque huiusmodi tractandi." 
11-12 Declamation on Libertas quae tamen sera respexit inertem [Verg. Ecl. 1.27].

Incipit: "Quamprimum his oculis spectabundis [sic]."

15-19 Declamation De hortulo (composed 8 June 1744, but delivered Friday 2 November 1744).

Incipit: "Instituenti mihi saepenumero."

20-22 Declamation on $O$ fortunatos nimium si bona norint agricolas [Verg. Georg. 2.458] (dated Friday 15 March 1745).

Incipit: "Tandem aliquando, auditores admodum literati, Tusculanum nostrum." 23-5 Declamation on Qui studet optatam cursu contingere metam / multa [...] vino [Hor. Ars 412] (dated Friday 28 February 1745/1746).

Incipit: "Summa varietate rerum, quae Yalenses versamur."

26-8 Declamation on de Corydon, Alexi trahit sua quemque voluptas [Verg. Georg. 2.65].

Incipit: "Quaecumque vivendi ratio sit in suo genere."

[66] 1743 - Thomas Prince, Oratio valedictoria Cantabrigiae in comitiis habita Iulii 6, 1743 [...] prope solis occasum

Boston, MA, Massachusetts Historical Society, ms. S-701, f. 14r-15r

Incipit: "Hodiernum diem, auditores clarissimi, quam illustrem iam vidimus."

[67] 1744 - James Logan, Fragment of a Letter to Dr. John Fothergill

Philadelphia, PA, Historical Society of Pennsylvania, James Logan Papers, 1670-1749, Collection 2011, Letter Book F, f. 12r-v.

Incipit: "Quod per aliquot retro annos."

[68] 1746 - Ezra Stiles, Oratio cliosophica (dated 17 July 1746)

New Haven, CT, Beinecke Rare Book and Manuscript Library, Yale University, Ezra Stiles Papers, MP 139.

Incipit: "Cogitanti mihi saepenumero, auditores colendissimi."

[69] 1747 - Pelatiah Webster, Letter to Ezra Stiles (dated 4 November 1747)

New Haven, CT, Beinecke Rare Book and Manuscript Library, Yale University, Ezra Stiles Papers, unknown shelfmark (ms. not seen).

Cited in E.S. Morgan, The Gentle Puritan. A Life of Ezra Stiles, 1727-1795 (New Haven, CT, 1962), 45.

[70] 1748 - James Logan, Letter to Hugh Jones (dated 22 April 1748)

Philadelphia, PA, Historical Society of Pennsylvania, James Logan Papers, 1670-1749, Collection 2011, Box 1, Folder 3.

Incipit: "Literas tuas Aprilis 13 per dominum Samuelem Domieri gratus accepi." 


\section{[71] 1748 - Ezra Stiles, Peroratio}

New Haven, CT, Beinecke Rare Book and Manuscript Library, Yale University, Ezra Stiles Papers, MP 82.

Incipit: "Vos, domini generosi, secundum morem usitatum."

[72] 1748 - William Johnson, Declamation on Nil tam difficile est quod non solertia vincat [Lily, Carmen de moribus, 30]

New Haven, CT, Beinecke Rare Book and Manuscript Library, Yale University, General Manuscripts Miscellany, Group 856, Box 3, Folder 105.

Incipit: "Cum hoc sit negotium."

[73] 1749 - Inscription to Ezra Stiles, College Tutor, Accompanying a Watch from Students (dated 25 May 1749)

New Haven, CT, Beinecke Rare Book and Manuscript Library, Yale University, Ezra Stiles Papers, MP 77, 9.

Incipit: "Domine benignissime, pro tuis multis beneficiis et paterna benevolentia."

[74] 1749 - Ezra Stiles, Exordium vel introductio ad candidatorum examinationem

New Haven, CT, Beinecke Rare Book and Manuscript Library, Yale University, Ezra Stiles Papers, MP 82.

Incipit: "Candidati dilecti, secundum morem huiusce academiae."

[75] 1749 - Ezra Stiles, Oratio valedictoria (dated 4 July 1749)

New Haven, CT, Beinecke Rare Book and Manuscript Library, Yale University, Ezra Stiles Papers, MP 81.

Incipit: "Quoniam convenimus, auditores, publicos academiae nostrae honores."

[76] 1749 - Ezra Stiles, Draft of Oratio valedictoria (dated 13 September 1749)

New Haven, CT, Beinecke Rare Book and Manuscript Library, Yale University, Ezra Stiles Papers, MP 83.

Incipit: "Artium liberalium laudes de hoc rostro, auditores."

[77] 1749 - Ezra Stiles, Delivered version of Oratio valedictoria (dated 13 September 1749)

New Haven, CT, Beinecke Rare Book and Manuscript Library, Yale University, Ezra Stiles Papers, MP 84.

Incipit: "Huiusmodi exercitia, auditores, multis iam annis ab oratoribus annuatim alternis peracta." 
[78] 1749 - Ezra Stiles, Drafts of an Academic Oration (dated 25 November 1749)

New Haven, CT, Beinecke Rare Book and Manuscript Library, Yale University, Ezra Stiles Papers, MP 87 (2 drafts)

Incipit: "Novum inter usitatas academiae consuetudines."

[79] 1750 - Ezra Stiles, Oratio habita ad pupillos (dated 8 September 1750) New Haven, CT, Beinecke Rare Book and Manuscript Library, Yale University, Ezra Stiles Papers, MP 98.

Incipit: "Etsi rebus gestis et disciplina liberali."

[80] 1750 - Ezra Stiles, Drafts of his Oratio funebris pro exequiis celebrandis viri perillustris Jonathan Law armigeri (New London, CT, 1751)

New Haven, CT, Beinecke Rare Book and Manuscript Library, Yale University, Ezra Stiles Papers, MP 100 (draft dated 23 November 1750).

Ibidem, MP 101 (fair copy for printer dated December 1750).

Ibidem, MP 101 (draft dated December 1750).

Ibidem, MP 102 (undated draft).

Ibidem, MP 103 (draft dated 12 December 1750).

Incipit: "Convenimus, auditores, exequias persolvere debitas."

[81] 1751 - Ezra Stiles, Oratio ad candidatorum examinationem habita (dated 18 July 1751)

New Haven, CT, Beinecke Rare Book and Manuscript Library, Yale University, Ezra Stiles Papers, MP 118.

Incipit: "Salvete, iuvenes ingenui necnon pro artium liberalium academiae nostrae honoribus laureis candidati."

[82] 1752 - Aaron Burr, Sr., Oration to the Trustees of the College of New Jersey

Princeton, NJ, Princeton University Library, Aaron Burr Collection, Box 1, Folder 3.

Incipit: "Anno iam illapso, curatores honorandi, apud haec concilia solemnia."

[83] 1752 - Ezra Stiles, Oratio quinquagenaria (dated 10 April 1752)

New Haven, CT, Beinecke Rare Book and Manuscript Library, Yale University, Ezra Stiles Papers, MP 129.

Incipit: "Quinquagenaria academiae nostrae anniversaria iam celebrata."

[84] 1752 - Ezra Stiles, Short Commencement Oration (dated 3 June 1752)

New Haven, CT, Beinecke Rare Book and Manuscript Library, Yale University, Ezra Stiles Papers, MP 77, 12.

Incipit: "Pro more academiarum in Anglia." 
[85] 1752 - Ezra Stiles, Exordium ad candidatorum examinationem (dated 17 July 1752)

New Haven, CT, Beinecke Rare Book and Manuscript Library, Yale University, Ezra Stiles Papers, MP 133.

Incipit: "Candidati dilecti, pro more academiarum in Anglia et universitatum Europearum."

[86] 1752 - Ezra Stiles, Oration to the President of Yale with Reply from the President

New Haven, CT, Beinecke Rare Book and Manuscript Library, Yale University, Ezra Stiles Papers, MP 138.

Incipit: "Honorande admodum et reverende praeses, morem iuxta academiarum in Anglia."

[87] 1752 - Ezra Stiles, Oratio semi-saecularis habita in comitiis publicis collegii Yalensis (dated 20 September 1752)

New Haven, CT, Beinecke Rare Book and Manuscript Library, Yale University, Ezra Stiles Papers, MP 135.

Incipit: "Illustrium, auditores, et virorum et rerum gestarum monumenta."

[88] 1752 - Ezra Stiles, Note of Thanks from Stiles to his Students for the Gift of a Gown (dated 20 December 1752)

New Haven, CT, Beinecke Rare Book and Manuscript Library, Yale University, Ezra Stiles Papers, MP 77, 15.

Incipit: "Pupilli amandi, pro hoc specimine."

[89] 1753 - Ezra Stiles, Note of Thanks when Presented with a Waistcoat by his Students

New Haven, CT, Beinecke Rare Book and Manuscript Library, Yale University, Ezra Stiles Papers, MP 77, 17.

Incipit: "Pupilli generosi et quam charissimi."

[90] 1753 - Ezra Stiles, Oratio cliosophica (dated 2 May 1753) [Written by Stiles for Thomas Seymour to Deliver]

New Haven, CT, Beinecke Rare Book and Manuscript Library, Yale University, Ezra Stiles Papers, MP 139.

Incipit: "Huiusmodi exercitia, auditores, ad promovendam literaturam."

[91] 1753 - Ezra Stiles, Oratio (dated 4 June 1753)

New Haven, CT, Beinecke Rare Book and Manuscript Library, Yale University, Ezra Stiles Papers, MP 140.

Incipit: "Pro more academiae nostrae, auditores." 
[92] 1753 - Ezra Stiles, Presentatio candidatorum ad praesidem in biblioteca post examen in aula (dated 18 July 1753)

New Haven, CT, Beinecke Rare Book and Manuscript Library, Yale University, Ezra Stiles Papers, MP 133, 8-12.

Incipit: "Praeses honorandi, pro more nostro solenni."

[93] 1753 - Ezra Stiles, In funere illustrissimi ac reverendissimi domini domini Georgii Berkeley, episcopi Cloynensis, qui Oxonii obiit Januarii 13 AD 1753. Oratio, quam publicis comitiis habuit Ezra Stiles Idibus Septembris anno Domini 1753

New Haven, CT, Beinecke Rare Book and Manuscript Library, Yale University, Ezra Stiles Papers, MP 143. Ibidem, MP 144 (a draft).

Incipit: "Superiori anno, auditores humanissimi, breviter pro meo more."

\section{[94] 1753 - Joseph Shippen, Oratio salutatoria}

Princeton, NJ, Princeton University Library, Shippen Family Collection, Box 1, Folder 10.

Incipit: "Munus hocce oratorium, auditores literatura clarissimi, quod optime nostis."

[95] 1753 - Christian Wedsted, Epyllion on Crossing the Atlantic

Bethlehem, PA, Moravian Archives, 253C Poetry Collections, Box 3, unmarked Folder.

Printed in G. Dennis, "Christian Wedsted's Journey from London to Pennsylvania. June 13 - September 14, 1753”, Unitas Fratrum 10 (1981), 86-96. Incipit: "Navigat in portu, portus cui pleura deusque."34

[96] 1753-1757 - Christian Wedsted, A Collection of Occasional Poetry in Hexameters and Rhyming Verse

Bethlehem, PA, Moravian Archives, 253C Poetry Collections, Box 3, unmarked folder, s.f.

Partly transcribed in J.M. McMahon, "Ein guter Lateinischer Poët. A Latin Lyricist on the Colonial Pennsylvania Frontier", in E. Kessler, H.C. Kuhn (ed.), Germania Latin - Latinitas Teutonica (München, 2003), 741-750.

(online: www.phil-hum-ren.uni-muenchen.de/GermLat/Acta/McMahon.htm).

[97] 1754 - Ezra Stiles, Oratio ad examen (dated 5 July 1754)

New Haven, CT, Beinecke Rare Book and Manuscript Library, Yale University, Ezra Stiles Papers, MP 133, 13.

Incipit: "Honorande praeses, rursus dici examinatoris auroram putamus."

${ }^{34}$ On the Moravian use of pleura ("side wound"), see P. Vogt, "'Honor to the Side.' The Adoration of the Side Wound of Jesus in Eighteenth-Century Moravian Piety", Journal of Moravian History 7 (2009), 83-106. 
[98] 1754 - Ezra Stiles, Draft of In gratulatione nobilissimi et amplissimi viri Benjamin Franklini armigeri Pensylvaniae (dated November 1754)

New Haven, CT, Beinecke Rare Book and Manuscript Library, Yale University, Ezra Stiles Papers, MP 155.

Printed in L.W. Labree et al. (ed.), The Papers of Benjamin Franklin, vol. 5 (New Haven, CT, 1962), 493-500.

Incipit: "Scientiae ideo apud Europaeos olim, nuper autem apud nos excoluntur."

[99] 1754 - Ezra Stiles, Oratio valedictoria (written 4 August 1764 for delivery by a "friend" [amico] in September)

New Haven, CT, Beinecke Rare Book and Manuscript Library, Yale University, Ezra Stiles Papers, MP 152.

Incipit: "Ad morem solennitatis huiusce finiendae, auditores humanissimi."

[100] 1754 - William Warner, Macaronic Oration delivered at Harvard College

Portland, ME, Maine Historical Society, ms. S-5439.

Incipit: "Viri honoratissimi ac tiptoptissimi, vos omnes."

[101] ca. 1755 - Peters, Samuel, Declamation on Stat sui cuique dies, breve et inseparabile tempus / omnibus est vitae sed famam extendere factis / hoc virtutis opus [Verg. Aen. 10.467-468]

New Haven, CT, Beinecke Rare Book and Manuscript Library, Yale University, General Manuscripts Miscellany, Group 1126, Folder 1.

Incipit: "Nihil horum temporalium stabile."

[102] 1755 - Silas Deane, Latin Declamation on Nulli tacuisse nocet, nocet esse locutum [Dist. Cat. 1.12]

New Haven, CT, Beinecke Rare Book and Manuscript Library, Yale University, General Manuscripts Miscellany, Group 856, Box 3, Folder 107.

Incipit: "Pro bona dispositione omnis societatis."

[103] 1755 - Ezra Stiles, Oratio ad examen (dated 17 July 1755)

New Haven, CT, Beinecke Rare Book and Manuscript Library, Yale University, Ezra Stiles Papers, MP 162.

Incipit: "Honorandi praeses, rursus diei examinationis.

[104] 1756 - Ezra Stiles, Salutatory Oration Written for Delivery by Winthrop Saltonstall (dated 3 August 1756)

New Haven, CT, Beinecke Rare Book and Manuscript Library, Yale University, Ezra Stiles Papers, MP 180.

Incipit: "Mediis hisce belli temporibus." 
[105] 1756 - Ebenezer Thayer, Thesis on Omnia ad salutem necessaria in sacris scripturis perspicue revelantur

Worcester, MA, American Antiquarian Society, Bowers-Flagg Family Papers (1756-1930), Box 3, Folder 4.

Incipit: "Per revelationem indicium supra naturale."

[106] 1757 - James Lovell, Two Orations to the Governor of the Massachusetts Bay Colony

Cambridge, MA, Harvard University Archives, HUA 757.51.

Incipit: "Praecellentissime domine, ad humiles suas domos."

Incipit: "Cogitante mihi et superiorum revolventi."

[107] 1759 - Francis Williams, Address in Hexameters to the Governor of Jamaica

No surviving ms. Printed in J. Gilmore, "The British Empire and the NeoLatin Tradition: The Case of Francis Williams", in B. Goff (ed.), Classics and Colonialism (London, 2005), 92-106.

Incipit: "Denique venturum fatis volventibus annum."

[108] 1758 - Joseph Reed, "Answers to Questions in Divinity" [A Harvard Commencement Thesis]

New York, NY, New York Historical Society, Joseph Reed Papers 17571785 (ms. not seen).

[109] 1759 - Jonathan Trumbull, Oratio salutatoria

Cambridge, MA, Harvard University Archives, HUC 6759.88.

Incipit: "Matris academiae anniversarium hodierno die."

[110] 1759 - Abraham Jarvis, Macaronic Oration delivered at Yale College (dated 21 June 1759)

New Haven, CT, Beinecke Rare Book and Manuscript Library, Yale University, General Manuscripts Miscellany, Group 856, Box 3, Folder 109.

Incipit: "Most worthy gentlemen, when I cast my eyes around."

[111] 1760 - Jeremy Belknap, Declamation

Cambridge, MA, Harvard University Archives, HUC 8762.324.2, Box 1, Folder 3.

Incipit: "Nil est in toto terrarum orbe."

[112] 1760 - Edward Wigglesworth, Epitaph for Henry Flynt

Cambridge, MA, Harvard University Archives, HUG 1399.94.

Incipit: "Huic tumulo mandantur exuriae." 
[113] 1761 - Stephen Hooper, Two Commencement Orations

Cambridge, MA, Harvard University Archives, HUC 6761.39, Items 7-8.

Item 7: Salutatory Oration.

Incipit: "Solitam horum comitiorum consuetudinem, quam hodiernus dies." Item 8: Valedictory Oration.

Incipit: "Etsi, auditores, has partes mihi permissas."

\section{[114] 1761 - Andrew Fuller, Declamatio}

Cambridge, MA, Harvard University Archives, HUC 8762.324, Box 1, Folder 7 (online: www.hollis.harvard.edu).

Printed in Harvard Graduates' Magazine 7 (September 1898), 43-44.

Incipit: "Scientiae cupido menti humanae naturaliter inest."

\section{[115] 1762 - Jonathan Trumbull, Oratio valedictoria}

Cambridge, MA, Harvard University Archives, HUC 6759.87.

Incipit: "Cursu nostro literato non infeliciter, ut sperem, confecto."

[116] 1763 - Joseph Hooper, Oratio salutatoria et valedictoria

Cambridge, MA, Harvard University Archives, HUC 6765.82.

Incipit: "Tametsi, auditores, nihil sit mihi iucundius aspectu vestro."

Incipit: "Non absque sensu tenuitates meae humillimae haec rostra."

[117] 1763 - Joseph Taylor, Oratio funebris in obitum Eduardi Wigglesworth

No surviving ms. Printed in A Faithful and Wise Servant, had in Honour, Throughout the Churches. A Discourse Occasioned by the Much Lamented Death of the Rev. Edward Wigglesworth, D.D. Hollis Professor of Divinity in Harvard College, Cambridge, vol. 2 (Boston, MA, 1765), 3-6.

Incipit: "Actum est! Vitam perfecit Wigglesworth."

[118] 1764 - Process of Publick Commencement in Nassau Hall at Princeton

No surviving ms. Printed in Ashbel Green, Discourses delivered in the College of New Jersey [...] Including an Historical Sketch of the College (New York, NY, 1822), 371-376.

Incipit: "Progredimini iuvenes."

\section{[119] 1768 - Eliphalet Pearson, Student Latin Compositions}

Cambridge, MA, Harvard University Archives, HUM 79, Box 1 (online: www.hollis.harvard.edu).

Folder 1: Freshman Latin Composition on Roman History.

Incipit: "Galli transgressi Alpes."

Folder 2: Various Fragments of Theses. 
Folder 3: Various Fragements of Theses.

Folder 4: Declamation on fas est ab hoste doceri.

Incipit: "Veritas sua natura est tam divina."

Folder 5: Declamation on Deus in omnibus assurget.

Incipit: "Aliquem dubitare existentiam."

Folder 6: Thesis on Idea substantiae incorporeae est aeque clara ac corporeae.

Incipit: "Ut veritas huiusce propositionis."

Folder 7: Declamation.

Incipit: "Ego, eu, omni erga me affectione."

Folder 8: Declamation.

Incipit: "Omnes homines, patres conscripti."

Folder 9: Declamation on Jugurtha.

Incipit: "Parvum ego te."

[120] ca. 1770 - David Humphreys, Latin Declamation from Yale College on Dimidium facti qui cepit habet sapere aude [Hor. Ep. 1.2.40]

New Haven, CT, Beinecke Rare Book and Manuscript Library, Yale University, General Manuscripts Miscellany, Group 2219, Folder 1.

Incipit: "Huius proverbii multas per vias."

[121] 1771 - William Wetmore, Oratio gratulatoria habita apud aedem Cantabrigiae Novae Angliae coram dominum Thoman Hutchinson

Cambridge, MA, Harvard University Archives, HUC 6771.93.

Incipit: "Quae res in concione duce plurimum possunt."

[122] 1772 - John Eliot, Oratio salutatoria

Cambridge, MA, Harvard University Archives, HUC 6772.30.

Incipit: "Quamquam mihi antea frequens."

[123] 1773 - Introduction to Catalogus librorum in Bibliotheca Cantabrigiensi selectus, frequentiorem in usum Harvardinatum, qui gradu baccalaurei in artibus nondum sunt donati (Boston, MA, 1773)

Incipit: "Cum catalogus librorum in bibliotheca Cantabrigiensi."

[124] 1775 - John Joachim Zubly, Exercitatio theologica de nuptiis Virginis superadultae (Charleston, SC, 1775)

Incipit: "In epistolis beati Pauli."

[125] 1776 - Noah Webster, Declamation on Iuventutem bene actam, senectutem parare felicem

New Haven, CT, Beinecke Rare Book and Manuscript Library, Yale University, General Manuscripts Miscellany, Group 553, Folder 3.

Printed in Yale Alumni Weekly (19 November 1926), 225.

Incipit: "Omnia argumenta, quibus uti necesse est in ullis rebus." 
[126] 1777 - Elijah Backus, Jr., Journal in Latin and English Written While a Student at Yale

New Haven, CT, Beinecke Rare Book and Manuscript Library, Yale University, General Manuscripts Miscellany, Group 752, Folder 3.

Partly printed in Connecticut Quarterly (October, 1895).

Incipit: "We have entered upon another year."

\section{[127] 1777 - Anonymous, Eulogy of John Wadsworth}

Portland, ME, Maine Historical Society, ms. S-779, Misc. Box 28/31.

Incipit: "M. S. Johannis Wadsworth A.M. in Academia Cantabrigiensi."

[128] 1778 - Ezra Stiles, Three Manuscript Drafts of his Oratio inauguralis (Hartford, CT, 1778)

New Haven, CT, Beinecke Rare Book and Manuscript Library, Yale University, Ezra Stiles Papers, MP 738.

Ibidem, MP 739.

Ibidem, MP 741.

Incipit: "Ineunte munus praesidile."

[129] 1778 - Ezra Stiles, Draft of a Letter to the Fellows of Yale College Discussing an Oration (dated 8 July 1778)

New Haven, CT, Beinecke Rare Book and Manuscript Library, Yale University, Ezra Stiles Papers, MP 740.

Incipit: "Reverendi socii, ablatam mihi vestram evocationem."

[130] 1778 - Samuel Whittelsey Dana, Oratio gratulatoria habita in sacello Collegii Yalensis 8 Iulii 1778

New Haven, CT, Beinecke Rare Book and Manuscript Library, Yale University, Ezra Stiles Papers, MP 743.

Incipit: "Convocatio nobis, qui celeberrimo."

[131] 1780 - Ezra Stiles, Oration to Degree Candidates (dated 19 July 1780)

New Haven, CT, Beinecke Rare Book and Manuscript Library, Yale University, Ezra Stiles Papers, MP 774.

Incipit: "Candidati dilecti, conspectus iucundissimo vestro."

[132] 1781 - Ezra Stiles, A Commencement Oration (dated 12 September 1781)

New Haven, CT, Beinecke Rare Book and Manuscript Library, Yale University, Ezra Stiles Papers, MP 801.

Incipit: "Periucunde semper, auditores, comitia academica." 
[133] 1782 - St John Honeywood, Oratio valedictoria (dated 20 July 1782) New Haven, CT, Beinecke Rare Book and Manuscript Library, Yale University, Ezra Stiles Papers, MP 820.

Ibidem, MP 821 [presentation copy].

Incipit: "Peractis tandem studiis academicis."

[134] 1782 - Anonymous, Two Declamations from Yale College (dated 30 August 1782)

New Haven, CT, Beinecke Rare Book and Manuscript Library, Yale University, General Manuscripts Miscellany, 856, Box 3, Folder 120, s.f.

Oratio de libertate.

Incipit: "Cum res multas iucundissimas reputarem."

A Declamation on Vivendi recte prorogat horam, / rusticus expectat dum defluat amnis: at ille. / Labitur et labetur in omne volubilis aevum [Hor. Ep. 2.42-3].

Incipit: "Fruitio felicitates semper fuit merito."

[135] 1783 - John Warren, Inaugural Oration Delivered at Harvard Medical School

Boston, MA, Massachusetts Historical Society, John Collin Warren Papers, Loose Manuscripts, Series 1, Folder 2.

Incipit: "Quoniam in hoc loco ornatissimo."

\section{[136] 1783 - Abiel Holmes, Declamations}

Cambridge, MA, Houghton Library, ms. Am. 1230.

1) f. 5v-6r: Declamation on Qui non vetat peccare cum possit, iubet [Sen. Troad. 291].

Incipit: "In hominum pectoribus desiderium gloriae."

2) f. 6v-9v: Declamation on Perdidit arma locum virtutis deseruit, qui / semper in augenda festinat et obruitur re [Hor. Ep. 16.67-68].

Incipit: "Sapientissime in curriculo vitae occurrit."

\section{[137] 1784 - Anonymous, Oratio}

New Haven, CT, Yale University, Sterling Library, RU 140, Box 4, Folder 34. Incipit: "Cum plurimis ingeniis hominum occupatis attendamus."

\section{[138] 1784 - Ezra Stiles, Epitaph of Ezra Stiles, Jr.}

New Haven, CT, Beinecke Rare Book and Manuscript Library, Yale University, Ezra Stiles Papers, MP 869.

Incipit: "Hae exuriae mortales." 
[139] 1786-1789 - Ezra Stiles, Various Drafts of Commencement Orations (dated 13 September 1786 to 9 September 1789)

New Haven, CT, Beinecke Rare Book and Manuscript Library, Yale University, Ezra Stiles Papers, MP 898.

[140] 1786 - Francis Withers, Oration on Receiving his A.M.

Cambridge, MA, Houghton Library, ms. Am. 715, Box 2, 184.

Incipit: "Quamquam initio dicendi haec frequentia maxime."

[141] 1786 - Elisha Sterling, Oratio de Ambitione (dated 8 March 1786)

New Haven, CT, Beinecke Rare Book and Manuscript Library, Yale University, General Manuscripts Miscellany, Group 1675, Folder 1.

Incipit: "Quoniam est maximi momenti."

\section{[142] 1787-1789 - Edward Dorr Griffin, Two Latin Declamations from Yale College}

New Haven, CT, Beinecke Rare Book and Manuscript Library, Yale University, General Manuscripts Miscellany, Group 1992, Folder 2, s.f.

Declamation on Omne tulit punctum, qui miscuit utile dulci [Hor. Ars 343] (dated 6 May 1789).

Incipit: "Homines natura et voluptati."

Declamation on Quo semel est imbuta recens servabit odorem / testa diu [Hor. Ep. 1.2.69-70] (dated 7 May 1787).

Incipit: "Est tempus in adolescentiis."

\section{[143] 1788 - John Phillips, Salutatory Oration}

Portsmouth, NH, New Hampshire Historical Society, ms. M 1977-007 (M).

Cambridge, MA, Harvard University Archives, HUC 6788.70.

Incipit: "Quamquam orator sine multitudine audiente eloquens."

\section{[144] 1788 - Samuel Perkins, Oratio valedictoria}

New Haven, CT, Beinecke Rare Book and Manuscript Library, Yale University, General Manuscripts Miscellany, Group 1119, Folder 1.

Incipit: "Septima aetas cum intra sedes musarum."

\section{[145] ca. 1789 - Joseph Grove, Letter to Joseph Goffe}

Worcester, MA, American Antiquarian Society, Joseph Goffe Papers, Miscellaneous Papers, Folder 3.

Incipit: "Dignissime condiscipule, cum epistolarum scriptionem."

[146] ca. 1790 - Joseph Dennie, Fragment of Oration Upon Receiving his A.M.

Cambridge, MA, Houghton Library, ms. Am. 715, Box 2, 178.

Incipit: "Dicendi initio tot ac tantorum hominum." 
[147] 1790 - Ezra Stiles, Letter to his Students Announcing the Winners of College Prizes (dated 25 March 1790)

New Haven, CT, Beinecke Rare Book and Manuscript Library, Yale University, Ezra Stiles Papers, MP 973.

Incipit: "Restat in manibus praesidis."

[148] 1791 - Ezra Stiles Commencement Oration (dated 25 September 1791)

New Haven, CT, Beinecke Rare Book and Manuscript Library, Yale University, Ezra Stiles Papers, MP 1000.

Incipit: "Socii reverendi, quorum candidati tam examini."

[149] 1791 - Ezra Stiles, Fragment of a Commencement Address

New Haven, CT, Beinecke Rare Book and Manuscript Library, Yale University, Ezra Stiles Papers, MP 1001.

Not seen.

[150] 1792 - Ezra Stiles, Oration (dated 24 July 1792)

New Haven, CT, Beinecke Rare Book and Manuscript Library, Yale University, Ezra Stiles Papers, MP 1032.

Incipit: "Optimates colendissimi necnon vos senatus."

[151] 1792 - Abiel Abbott, Oratio salutatoria

Cambridge, MA, Harvard University Archives, HUC 6792.2.

Incipit: "Celeberrimo anni hoc lato die."

[152] 1793 - Daniel Appleton White, Declamation from Harvard College (dated June 1793)

Cambridge, MA, Harvard University Archives, HUM 11, Box 1, Folder 1. Incipit: "Cum hunc mundum."

[153] 1793 - Daniel Appleton White, De alea (dated 31 July 1793)

Cambridge, MA, Harvard University Archives, HUM 11, Box 1, Folder 3. Incipit: "Innumerabiles hominum improbae cupiditates."

\section{[154] 1794 - Anonymous, Salutatory Oration from Princeton}

Princeton, NJ, Princeton University Library, John Witherspoon Collection, Box 1, Folder 2.35

Incipit: "Auditores praestantissimi et spectatissimi, quando oculis circumspiciens hunc coetum."

\footnotetext{
${ }^{35}$ The catalog calls it erroneously "John Witherspoon, Funeral Oration for Meredith Clymer."
} 


\section{[155] 1799 - James Luce Kingsley, Salutatory Oration}

New Haven, CT, Yale University, Sterling Library, RU 140, Box 4, Folder 38. Incipit: "Praeses reverende, socii honorandi ac reverendi, in his comitiis academiae publicis."

[156] s.d. - Anonymous, Oratio

New Haven, CT, Yale University, Sterling Library, RU 140, Box 4, Folder 36. Incipit: "Hodierna die, domini examinatores."

[157] s.d. - Anonymous, Poema ad Regem [probably addressed to George II]

Cambridge, MA, Houghton Library, ms. Am. 813, Item 28.

Incipit: "Dum longe exultans diffundit buccina fama."

[158] s.d. - William Welsteed, Translation into Hexameters of Benjamin Colman, "A Hymn of Praise on a Recovery from Sickness"

Boston, MA, Massachusetts Historical Society, Benjamin Colman Papers, ms. N-1013, Box 1, Folder 1, Item 2 (online: www.masshist.org).

Incipit: "O auctor vitae, quae dulcia cantica laudis."

Chinese University of Hong Kong smcmanus@cuhk.edu.hk 


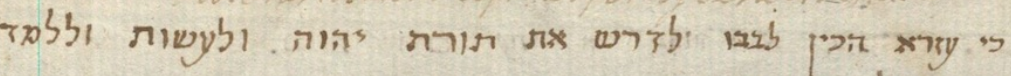

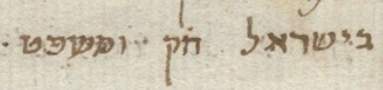

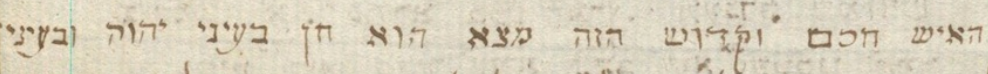

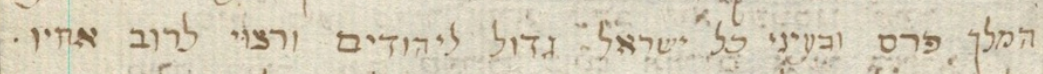

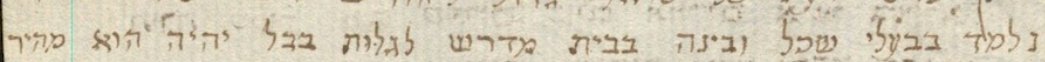

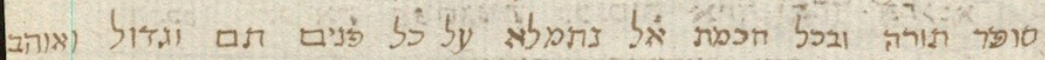

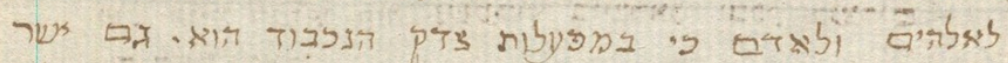

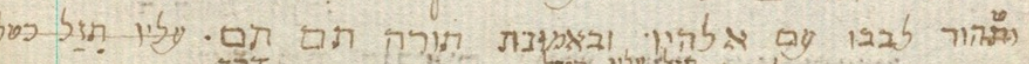

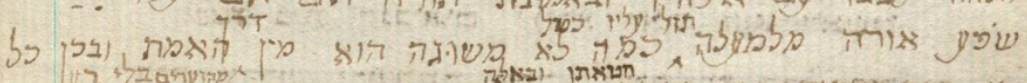
87 7 לे

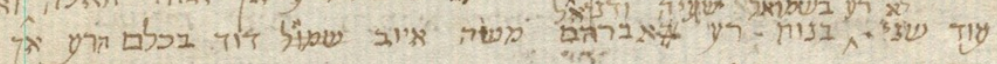

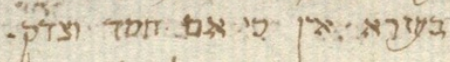
$b=2$ ב

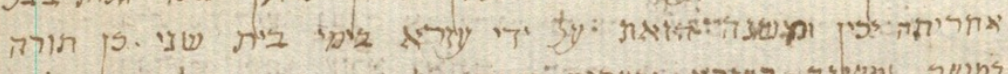

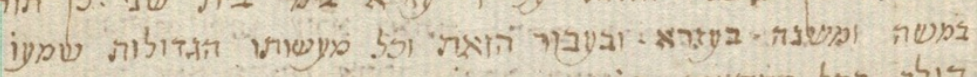

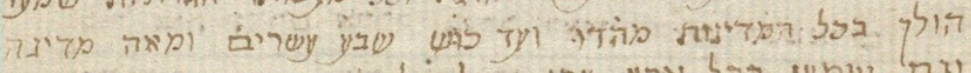

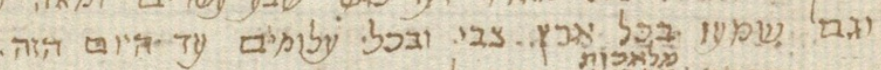

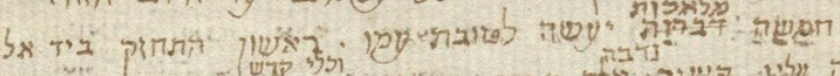

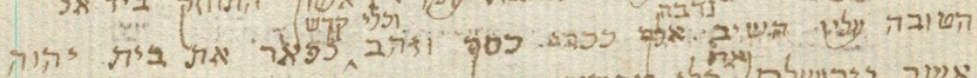

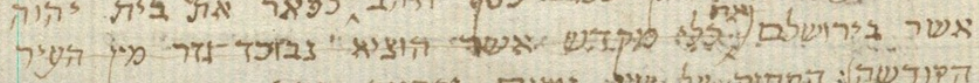

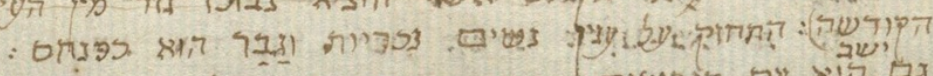

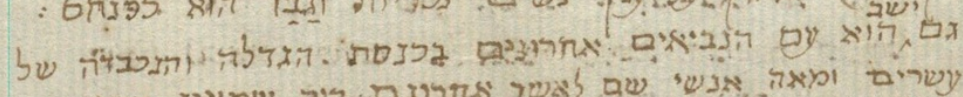

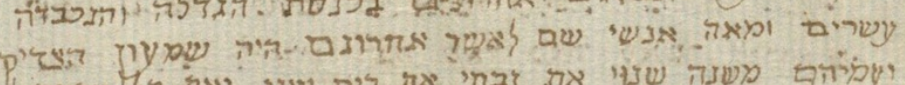

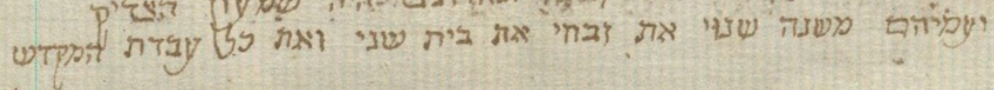

Plate 1: The first page of an oration delivered by Stiles in Hebrew, dated 12 September 1782 (New Haven, CT, Beinecke Rare Book and Manuscript Library, Yale University, Ezra Stiles Papers, MP 802, f. 1r). 


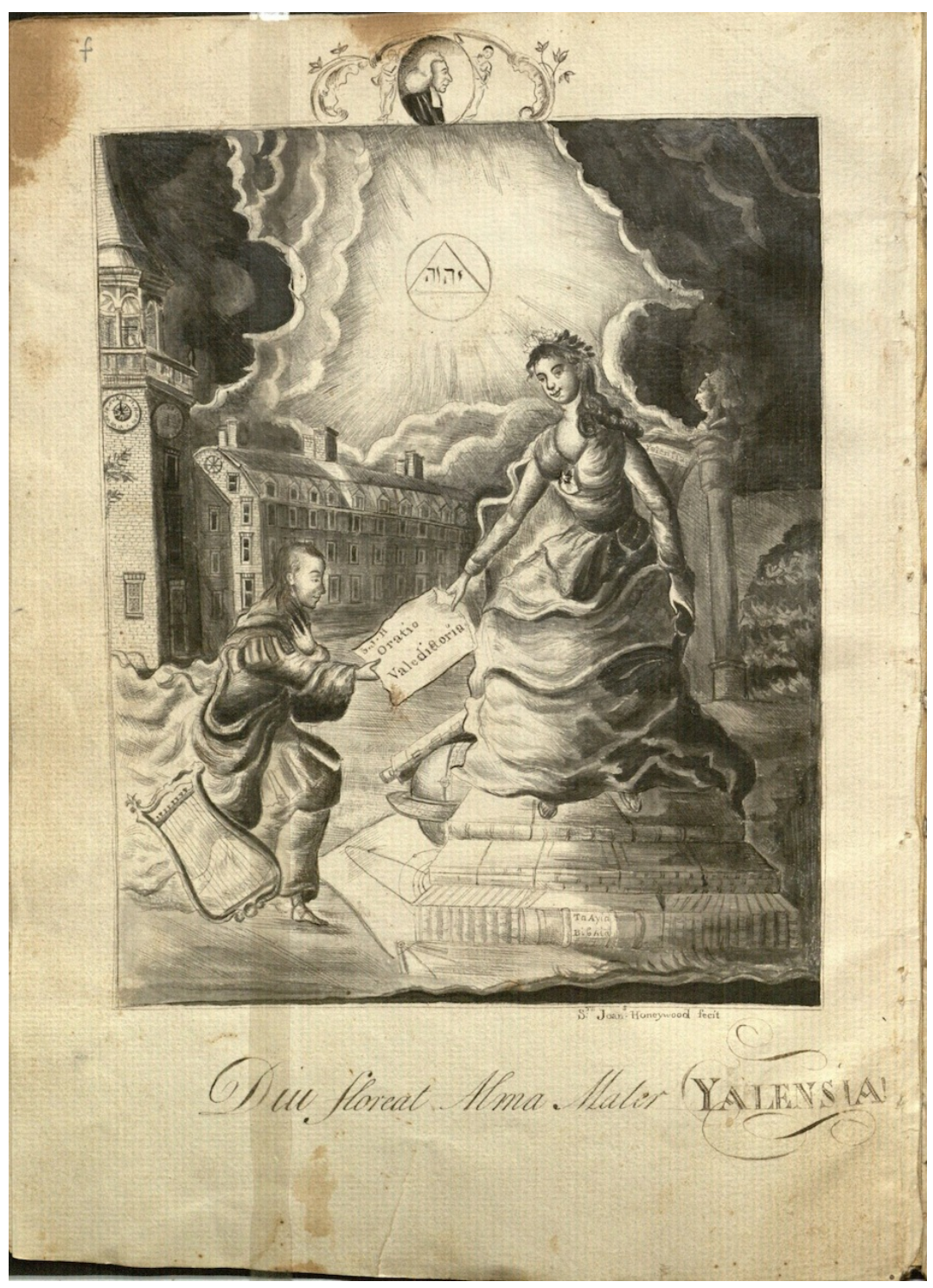

PLATE 2: St. John Honeywood's presentation copy of his college oration, 1782 (New Haven, CT, Beinecke Rare Book and Manuscript Library, Yale University, Ezra Stiles Papers, MP 821, frontispiece). 
